\title{
PROGNOSIS AFTER TREATMENT OF CERVICAL CANCER IB1: COMPARISON BETWEEN RADICAL HYSTERECTOMY TYPE II AND TYPE III
}

F.L. Cordero' ${ }^{1}$, K.A.S. Almeida², F.B. Russomano¹, D. Salles², F.A.R. Fleming' ${ }^{2}$, A.D. Bottino², A.P.P. Dal Magro². ${ }^{1}$ Instituto Nacional de Câncer José Alencar Gomes da Silva INCA, Oncological Surgeon, Rio de Janeiro, Brazil. 2Instituto Nacional de Câncer José Alencar Gomes da Silva INCA, Oncological Surgery Resident, Rio de Janeiro, Brazil.

Objectives: The study compared the postoperative prognosis in patients with cervical cancer Ib1 (FIGO 1988) with more than $2 \mathrm{~cm}$, operated by the Piver II and Piver III techniques in a hospital sample in Rio de Janeiro.

\begin{tabular}{ccccc} 
& Piver II & Piver III & Total & p-valor \\
\hline $\begin{array}{c}\text { Número de pacientes } \\
\text { (\%) }\end{array}$ & $70(47,3)$ & $78(52,7)$ & $148(100)$ & - \\
\hline $\begin{array}{c}\text { Idade média em anos } \\
\text { (DP) }\end{array}$ & $45,99(12,2)$ & $46,40(12,11)$ & $46,2(12,07)$ & $0,7424^{*}$ \\
$\begin{array}{c}\text { Número médio de } \\
\text { parceiros (DP) }\end{array}$ & $2,47(0,847)$ & $2,9(1,392)$ & $2,69(1,17)$ & $0,003^{*}$ \\
$\begin{array}{c}\text { Tabagismo a época do } \\
\text { diagnóstico (\%) }\end{array}$ & $28(47,5)$ & $31(52,5)$ & $59(39,8)$ & $0,975 \dagger$ \\
\hline
\end{tabular}

\section{$\dagger$ Teste do Exato de Fisher}

Table 1: Characteristics of the tumor and the surgical sample resulting from the treatment (INCA, 2009-2014).

Methods: The method used consists of a historical analysis of a group of women with cervical cancer in the mentioned stage submitted to the two surgical techniques analyzed. The work seeks to compare them to find an outcome of interests, considering data related to the disease, treatment and posttreatment follow-up obtained in the medical records.

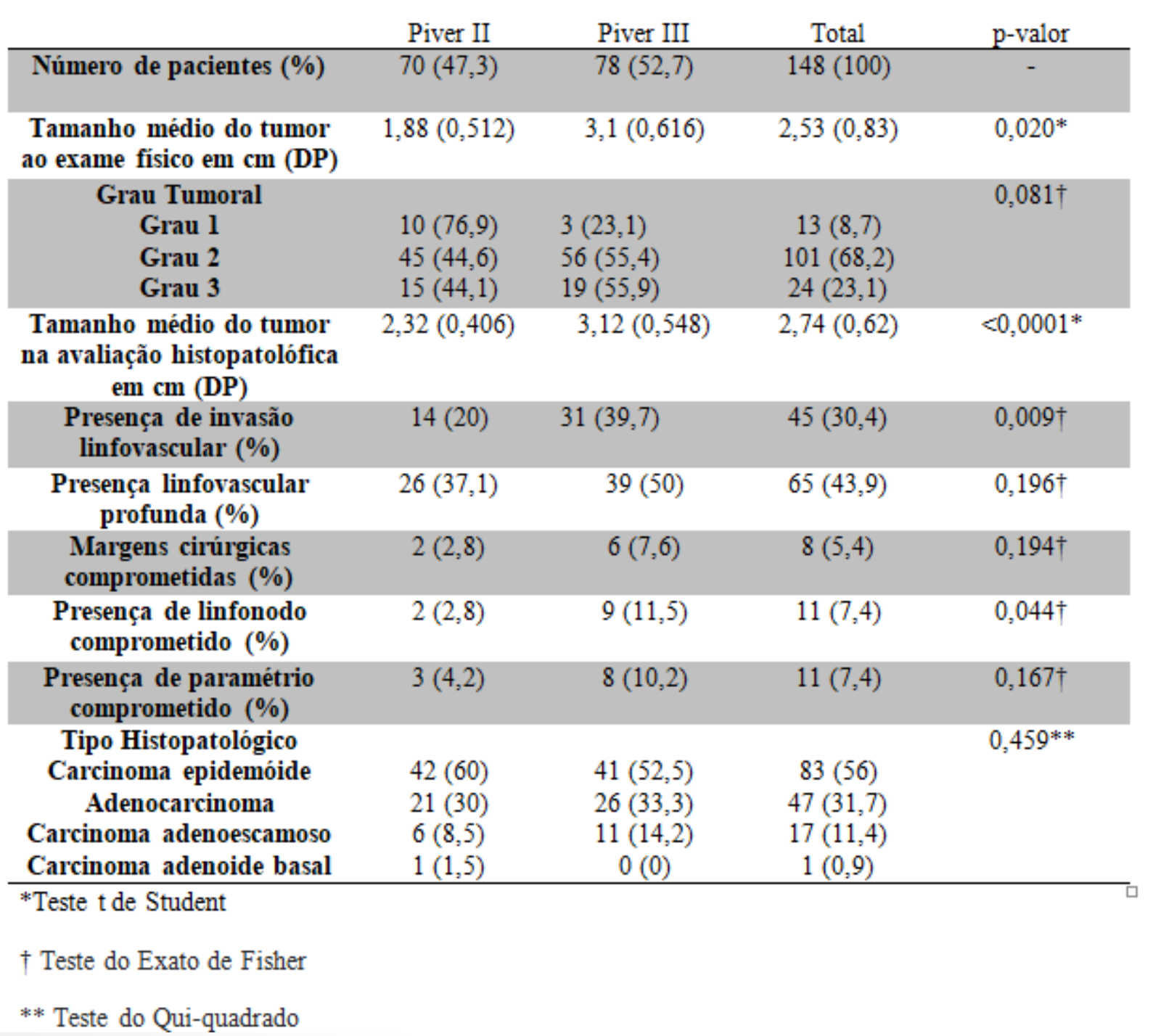

Results: Patients submitted to both surgical techniques did not have a significant difference in overall and disease-free survival. Prognostic factors, such as lymphatic, parametrial impairment, surgical margins, deep invasion of miocervix and lymphovascular space were shown to be related to worse global and disease-free survival.

\begin{tabular}{|c|c|c|c|c|}
\hline \multirow[b]{2}{*}{$\begin{array}{c}\text { Fator } \\
\text { prognóstico }\end{array}$} & \multicolumn{2}{|c|}{$\begin{array}{l}\text { Densidade de Incidência } \\
\text { (por } 1.000 \text { pacientes-mês) }\end{array}$} & \multicolumn{2}{|c|}{$\begin{array}{c}\text { Razão das taxas de } \\
\text { densidade de incidência } \\
\text { (IC } 95 \% \text { ) }\end{array}$} \\
\hline & Piver II & Piver III & $\begin{array}{l}\text { Recorrência } \\
\text { locorregional }\end{array}$ & Óbito \\
\hline $\begin{array}{l}\text { Presença de } \\
\text { linfonodo } \\
\text { comprometido }\end{array}$ & 0,43 & 1,65 & - & - \\
\hline $\begin{array}{c}\text { Margens } \\
\text { cirúrgicas } \\
\text { comprometidas }\end{array}$ & 0,43 & 1,10 & $\begin{array}{c}1,88 \\
(0,72-4,91)\end{array}$ & - \\
\hline $\begin{array}{l}\text { Presença de } \\
\text { paramétrio } \\
\text { comprometido }\end{array}$ & 0,65 & 1,47 & $\begin{array}{c}3,04 \\
(1,58-5,99)\end{array}$ & $\begin{array}{c}5,37 \\
(2,55-11,3)\end{array}$ \\
\hline $\begin{array}{l}\text { Presença de } \\
\text { invasão } \\
\text { profunda }\end{array}$ & 5,67 & 7,17 & $\begin{array}{c}2,19 \\
(1,11-4,34)\end{array}$ & $\begin{array}{c}5,05 \\
(1,75-14,47)\end{array}$ \\
\hline $\begin{array}{l}\text { Presença de } \\
\text { invasão } \\
\text { linfovascular }\end{array}$ & 3,05 & 5,70 & $\begin{array}{c}2,18 \\
(1,20-3,96)\end{array}$ & $\begin{array}{c}3,77 \\
(1,70-8,35)\end{array}$ \\
\hline
\end{tabular}

Table 3: Incidence density rates for locoregional recurrence and death according to the presence of the prognostic factors studied (INCA, 2009-2014).

Conclusions: Although there was no difference in overall and disease free survival, the group submitted to type III showed more severe tumors, so it would not be possible through the study to suggest a change in technique.

Sources:

1) Inca. Estimativas da incidência e mortalidade por câncer. Disponível online em http://www.inca.gov.br/estimativa/2016/estimativa-2016- v11.pdf.

2) Ditto A, Martinelli F, Ramondino S, Vullo SL, Carcangiu M, Haeusler E, Mariani L, Lorusso D, Raspagliesi F. Class II versus Class III radical hysterectomy in early cervical cancer: An observational study in a terciary center. Eur J Surg Oncol, 2014; 40:883-890.

3) Ryu ST, Kim MH, Nam BH, Lee TS, Song ES, Park CS, Kim JW, Kim YB, Ryu HS, Park SY, Kim KT, Cho CH, Lee C, Kim SM, Kim BG, Bae DS, Kim YT, Nam J-H. Intermediate-risk grouping of cervical cancer patients treated with radical hysterectomy: a Korean Gynecologic Oncology Group study. Br J Cancer. 2014 21; 110(2):278-8

4) Randall ME, Fracasso PM, Toita T, Tedjarat, SS, Michael H . Cervix, in Barakat, RR; Markman, M; Randall, ME. Principles and Practice of Gynecologic Oncology. Lippincott Williams \&Wilkins, 2013, 598p. 